\title{
A coragem de ser só: Cândido Mendes de Almeida, 0 arauto do ultramontanismo no Brasil
}

The courage to be alone: Cândido Mendes de Almeida, the herald of ultramontanism in Brazil

\section{İtalo Domingos Santirocchi \\ Professor Adjunto do Curso de Licenciatura em Ciências Humanas da Universidade Federal do Maranhão, Campus Pinheiro (UFMA - Pinheiro/Brasil) e-mail: italosantirocchi@hotmail.com}

\begin{abstract}
Resumo
A construção do Estado Imperial foi, e continua sendo, objeto de vários estudos e pesquisas. No entanto, um aspecto parece continuar sendo negligenciado. 0 Império do Brasil era um Estado Confessional, existindo a união entre os poderes secular e espiritual. Juntamente com as propostas políticas, também foram elaborados diferentes projetos para a Igreja Católica no Brasil. A partir dos anos de 1840, o ultramontanismo foi se tornando o movimento católico mais proeminente frente a outros projetos. Cândido Mendes de Almeida foi um dos fiéis que mais contribuiram para essa causa, não só como político e jurista, mas também como historiador. No entanto, sua vida e sua obra ainda não receberam a merecida atenção por parte dos historiadores brasileiros. Este artigo busca lançar luz sobre a biografia e a obra de Cândido Mendes de Almeida.
\end{abstract}

\section{Abstract \\ The construction of the Imperial State has been and still remains object of many studies and researches. However, a point seems to remain neglected. The Empire of Brazil was a "Confessional State", existing a unity between secular and spiritual powers. Along with the proposed policies, there was a variety of projects developed by the Catholic Church in Brazil. From the 1840s, the ultramontanism became the most prominent Catholic movement. Cândido Mendes de Almeida was one of the faithful who most contributed to this cause, not only as a politician and jurist, but also as a historian. However, his life and his work have not received the deserved attention by Brazilian historians. This article wants to raise awareness about the biography and work of Cândido Mendes de Almeida.}

Palavras-chave

Estado Imperial, Igreja, Ultramontanismo

Keywords

Imperial State, Church, ultramontanism 
$\mathrm{Na}$ antiguidade clássica e no medievo a biografia foi, por vezes, considerada uma modalidade de conhecimento diferente da história [LORIGA, Sabina. A biografia como problema. In: REVEL, J. (Org.). Jogos de escalas: a experiência da microanálise. Rio de Janeiro: FGV, 1998. p. 228-229].

3

BARROS, José D'Assunção. 0 campo da história, especialidades e abordagens. Petrópolis: Editora Vozes, 2008. p. 186-206.

4

LORIGA, Sabina. Op. Cit. p. 231.

5

LEVI, Giovanni. Usos da biografia. In: FERREIRA, Marieta de Moraes e AMADO, Janaina (Orgs.). Usos e abusos da História Oral. Rio de Janeiro: FGV, 2006. p. 172.

6 BARROS, José D'Assunção. Op. Cit. p. 188.
"A coragem de ser só, Cândido Mendes a teve, e a teve com uma intensidade impressionante" ${ }^{\text {. }}$.

\section{Introdução}

Seguindo as divisões apresentadas por José d'Assunção Barros no livro 0 Campo da História, especialidades e abordagens, é possivel classificar as atuais biografias históricas como um domínio ou abordagem da historiografia. A biografia como domínio é tão antiga quanto a história e, por vezes, se confunde com o gênero literário². No caso deste artigo o objetivo é encará-la como uma abordagem, ou seja, um campo de observação, ou um meio para adentrar em um universo mais amplo ${ }^{3}$. No nosso caso, esses universos são a História das Religiões, a História Política e a História Social do Brasil imperial.

No século XIX, as biografias continuaram em voga, mas a dimensão individual era sacrificada em busca de traços gerais, exemplares, que evidenciassem as "leis gerais da sociedade" ${ }^{4}$. Era privilegiada a dimensão pública em vez da dimensão privada ${ }^{5}$. As transformações que sofreu a historiografia a partir dos anos trinta do século $X X$, com sua crítica à história como praticada no século XIX, acabou desprestigiando a biografia, mesmo que o fundador dos Annales, Lucien Febvre, tenha realizado trabalhos nessa área. Esta abordagem foi relegada a um espaço entre a história e a literatura, pouco frequentada por historiadores profissionais e muito mais por literatos e jornalistas. Esse cenário mudou somente a partir dos anos setenta, quando os historiadores retomaram esse domínio. Segundo Barros:

\begin{abstract}
Agora os mais variados sujeitos históricos merecem ser biografados: não apenas os heróis e as grandes individualidades políticas, mas também os indivíduos anônimos que jamais sairiam dos arquivos empoeirados se de lá não os tivesse arrancado os historiadores - um moleiro herético, um padre exorcista de segundo plano, um impostor que se faz passar por um marido desaparecido até ser desmascarado, e que carrega em sua própria vida um enredo tão novelesco que se tornou matéria-prima para produção cinematográfica ${ }^{6}$.
\end{abstract}

Apesar da ênfase nos individuos "desconhecidos" ou "marginalizados" presente na citação acima, nas últimas décadas do século XX as biografias de indivíduos ilustres também retornaram, principalmente na historiografia francesa e inglesa, com trabalhos de Jacques Le Goff, Georges Duby, Christopher Hill.

As críticas surgidas ao estruturalismo e às mentalidades permitiram o ressurgimento dos indivíduos e da individualidade, a discussão sobre a possibilidade de liberdade individual, seu reflexo na sociedade e na história. Uma das correntes pioneiras no resgate da biografia foi a micro-história, gênero ainda pouco compreendido no Brasil, apesar de muito divulgado. Segundo Giovanni Levi, nas pesquisas biográficas atuais se deveria indagar:

[...] mais sobre a verdadeira amplitude da liberdade de escolha. Decerto essa liberdade não é absoluta: culturalmente e socialmente determinada, limitada, pacientemente conquistada, ela continua sendo no entanto uma liberdade consciente, que os interstícios inerentes aos sistemas gerais de normas deixaram aos atores. Na verdade nenhum sistema normativo é suficientemente estruturado para eliminar qualquer possibilidade de escolha consciente, de manipulação ou interpretação das regras, de negociação. A meu ver a biografia é por isso mesmo o campo ideal para verificar o caráter intersticial - e todavia importante - da liberdade de que dispõem os agentes e para observar como funcionam concretamente os sistemas normativos, que jamais estão isentos de contradições?. 
DEL PRIORE, Mary. Biografia: quando a indivíduo encontra a história. Revista Topoi, Rio de Janeiro jul./dez. 2009, vol. 10, n. 19, UFRJ. p. 9.

9

LEVI, Giovanni. Sobre a micro-história. In: BURKE, Peter (org). A escrita da História, novas perspectivas. São Paulo: Editora Unesp, 1992. p. 133-162.

10

DEL PRIORE, Mary. Op. Cit. p. 11.

11

Com relação às obras de contexto a respeito da Igreja no século XIX, indicamos algumas obras consultadas, com intuito de orientar o leitor: AZEVEDO, Thales de. A religião civil brasileira: um instrumento político. Petrópolis: Vozes. 1981; . Igreja e Estado em tensão e crise:

a conquista espiritual e o padroado na Bahia. São Paulo: Ática, 1978; AZZI, Riolando. 0 movimento brasileiro de reforma católica durante o século XIX. In: REB 34, 1974. p. 646-663; episcopado do Brasil frente ao catolicismo popular. Petrópolis: Vozes, 1977; o catolicismo popular no Brasil. Petrópolis: Vozes, 1978; . O Altar unido ao Trono: um projeto

conservador. São Paulo: Paulinas, 1992; BASTIDE, Roger, Religion and the Church in Brazil. In: Smith, T. Lynn - Marchant, Alexander, Brazil: Portrait of Half Continent. New York: The Dryden Press, 1951; BASTOS, Ana Marta Rodrigues. Católicos e Cidadãos: a Igreja e a Legislação Eleitoral no Império. Rio de Janeiro: Lúmen Júris, 1997; BEOZZO, José Oscar. Irmandades, Santuários, Capelinhas de Beira de Estrada. In: REB, Petrópolis, Vol. 37, 1977; BEOZZO, José Oscar (org.). História da Igreja na América Latina. T. II/2. Petrópolis: Vozes, 1992; BOEHRER, George C. A Igreja no Segundo Reinado: 1840-1889. In: KEITH, Henry H. \& EDWARDS S. $\mathrm{F}$ (orgs). Conflito e continuidade na sociedade brasileira. Rio de Janeiro: Civilização Brasileira, 1970; CAMARGO, Paulo Florência da Silveira. História eclesiástica do Brasil, Petrópolis: Vozes, 1955; DORNAS FILHO, João. O Padroado e a Igreja brasileira. São Paulo: Companhia Editora Nacional, 1938; DUTRA NETO, Luciano. Das terras baixas da Holanda às montanhas de Minas. Tese (Doutorado em História). 2006. Universidade de Juiz de Fora, Juiz de Fora. 2006; NEVES, Guilherme Pereira das. E receberá mercê: a Mesa de Consciência e Ordens e o clero secular no Brasil 1808-1828. Rio de Janeiro: Arquivo Nacional, 1997 A religião do império e a Igreja. In: GRINBERG, Keila \& SALLES, Ricardo (orgs). O Brasil Imperial, vol. 1. Rio de Janeiro: Civilização Brasileira, 2011; PEREIRA, Nilo. Conflitos entre a Igreja e o Estado no Brasil. Recife: Editora Massangana, 1982; SANTIROCCHI, Ítalo D. Os ultramontanos no Brasil e o regalismo do Segundo Império (1840-1889). Tese (Doutorado em História e Bens Culturais da Igreja). 2010. Pontifícia Universidade Gregoriana, Roma. 2010 Uma questão de revisão de conceitos: Romanização - Ultramontanismo Reforma. In: Temporalidades - Revista Discente do Programa de Pós-graduação em História da UFMG, Belo Horizonte, v. 2, n. 2, 2010. p. 24-33; SANTOS, José Augusto. Liberalismo eclesiástico e regalista no Brasil sob o pontificado de Gregório XVI. Tese (Doutorado em História Eclesiástica) 1971. Pontifícia Universidade Gregoriana, Roma. 1971; SOUZA, Françoise Jean de Oliveira. Do Altar à Tribuna. Os
Utilizando algumas das metodologias da microanálise pretendemos apresentar um importante personagem do Império: Cândido Mendes de Almeida que, apesar de ter sido um homem público no seu tempo, é pouco conhecido e pesquisado pela historiografia. 0 reduzido número de pesquisas sobre ele possibilita a utilização de técnicas da micro-história e, ao mesmo tempo, possibilita a elaboração de uma "biografia-problema", muito utilizada para as atuais biografias de indivíduos que se destacaram durante sua vida. Segundo Mary Del Priore, referindo-se ao ressurgimento da abordagem biográfica:

A reabilitação da biografia integrou as aquisições da história social e cultural, oferecendo aos diferentes atores históricos uma importância diferenciada, distinta, individual. Mas não se tratava mais de fazer, simplesmente, a história dos grandes nomes, em formato hagiográfico - quase uma vida de santo -, sem problemas, nem máculas. Mas de examinar os atores (ou o ator) célebres ou não, como testemunhas, como reflexos, como reveladores de uma época. A biografia não era mais a de um indivíduo isolado, mas, a história de uma época vista através de um indivíduo ou de um grupo de indivíduos. Ele ou eles não eram mais apresentados como heróis, na encruzilhada de fatos, mas como uma espécie de receptáculo de correntes de pensamento e de movimentos que a narrativa de suas vidas torna mais palpáveis, deixando mais tangivel a significação histórica geral de uma vida individual ${ }^{8}$.

Neste tipo de abordagem, o objetivo não é se concentrar exclusivamente nos indivíduos em si mesmos, mas, por meio deles, examinar a sociedade que os circunda. Eles são fragmentos (micro) de uma realidade ampla (macro) que se quer conhecer, ou são integrantes de problemas históricos específicos que se procura entender. Nas palavras de Levi, o indivíduo é uma redução da escala de observação, com a específica finalidade de analisar uma problemática mais ampla, confirmando ou criticando teorias e conceitos mais gerais?.

Segundo Del Priore, isso "implica o estudo de um indivíduo ou de grupo de individuos que representam uma classe social, uma profissão, uma fé ou crença, desde que se defina, previamente, a estrutura social a que pertençam" 10 . Ou seja, o indivíduo objeto de estudo é escolhido porque permite adentrar as problemáticas de interesse do pesquisador. No caso deste artigo especifico, é compreender como os laicos se integraram ao movimento de reforma católica levada a cabo pelos ultramontanos a partir de 1840 e sua relação com o Estado".

É importante tentar trabalhar o indivíduo numa configuração relacional, integrá-lo numa "configuração social" seguindo o raciocínio de Levi. No entanto, não se pode deixar de dar atenção à liberdade dos indivíduos no interior dos grandes sistemas normativos que o envolvem, pois "o poder deixa sempre uma margem de liberdade, uma margem que cria uma 'intersticialidade' e a possibilidade de mover-se entre as contradições dos sistemas normativos" 12 . Segundo Jacques Revel, o objetivo é mostrar, "por trás da tendência geral mais visivel, as estratégias sociais desenvolvidas pelos diferentes atores em função de sua posição e de seus recursos respectivos, individuais, familiares, de grupos, etc." ${ }^{13}$

Nas palavras de Mary Del Priore, o indivíduo não existe só, ele existe "numa rede de relações sociais diversificadas", sendo que, na "vida de um indivíduo, convergem fatos e forças sociais, assim como o indivíduo, suas ideias, representações e imaginários convergem para o contexto social ao qual ele pertence". Os indivíduos estão situados no meio de diversas redes 
padres políticos na formação do Estado Nacional brasileiro (1823 - 1841). Tese (Doutorado em História). 2010. Universidade do Estado do Rio de Janeiro, Rio de Janeiro. 2010; VIEIRA, David Gueiros. 0 protestantismo a maçonaria e a questão religiosa no Brasil. Brasilia: Editora Universidade de Brasilia, 1980; VIEIRA, Dilermando Ramos. O processo de Reforma e reorganização da Igreja no Brasil (18441926). Aparecida: Editora Santuário, 2007; WERNET Augustin. A lgreja Paulista no século XIX. A reforma de D. Antônio Joaquim de Melo (1851 - 1861). São Paulo: Ática, 1987.

12

LEVI, Giovanni, Entrevista, 1999. http:// escuelahistoria.fcs.ucr.ac.cr/contenidos/modhis/e-levi-cost.htm. Último acesso 06/08/2012.

13

REVEL, Jacques. Microanálise e construção do social. In: REVEL, J. (Org.). Jogos de escalas: a experiência da microanálise. Rio de Janeiro: FGV, 1998, p. 22.

14

DEL PRIORE, Mary. Op. Cit. p. 10.

15

REVEL, Jacques. Op. Cit. p. 25.

16

BOURDIEU, Pierre. A ilusão biográfica. In: REVEL, J. (Org.). Op. Cit. p. 183-191.

17

BARROS, José D'Assunção. Op. Cit. p. 200. 18

SÁ VIANNA, Manuel Álvaro de Souza. Comemoração do centenário natalício do Senador Cândido Mendes de Almeida (Elogio histórico lido na sessão do IHGB, de 14 de outubro de 1918). In: RIHGB, Rio de Janeiro, Imprensa Nacional, t. 83, 1919; VILLAÇA, Antônio Carlos. O Senador Cândido Mendes. Rio de Janeiro: EDUCAM, 1981; RODRIGUES J. H. Introdução. In: ALMEIDA, Cândido Mendes de. Pronunciamentos parlamentares 1871 a 1873. T. 1. Brasília: Senado Federal, Sociedade brasileira de Instrução, 1982. entrecruzadas: "a casa e a família, o espaço regional, o universo espiritual, a utensilagem mental de uma época"14. Esta situação leva a questionar sobre a "construção de identidades sociais plurais e plásticas que se opera por meio de uma rede cerrada de relações (de concorrência, de solidariedade, de alianças, etc.)" ${ }^{15}$. Neste ponto, cabe lembrar as críticas de Pierre Bourdieu no seu clássico texto $A$ ilusão biográfica, no qual ele termina provocando os biógrafos a considerarem um sujeito multi-identitário, formado por múltiplos "eus" em diferentes espaços de ação e em diferentes temporalidades da vida ${ }^{16}$

0 fato de Cândido Mendes de Almeida ser um personagem ilustre no seu tempo apresenta uma ulterior problemática ao se tentar traçar sua biografia: ele já foi objeto de uma "construção" da sua própria imagem a partir do seu tempo e também objeto de "construção" da sua memória, por meio dos seus biógrafos, homenagens e elogios fúnebres. Segundo Barros, esses indivíduos começam a ser construídos "coletivamente em paralelo à sua existência física e concreta".17

Um personagem como o que se quer aqui trabalhar deveria ser primeiramente "desconstruído", para somente depois ser analisado. Porém, o leitor poderá perceber, durante a leitura, a dificuldade de se fazer tal "desconstrução", pois os relatos que nos chegaram sobre Cândido Mendes apresentam um homem praticamente sem contradições, sem dramas internos evidentes, praticamente linear no seu percurso de vida ${ }^{18}$. Tal fato evidencia uma forte construção da memória, que buscou esconder seus traços contrastantes, ou um personagem sui generis, totalmente fiel e leal às suas convicções, que permaneceram perenes por toda sua trajetória de vida.

Cândido Mendes é, ao mesmo tempo, importante para a história do século XIX e tão relegado ao esquecimento pela historiografia. Seria necessário um trabalho muito mais amplo e minucioso daquele aqui proposto, para tentar perceber os traços mais sutis da personalidade e da trajetória do nosso personagem, caracteristicas que poderiam apresentar ulteriores aspectos da relação existente entre a Igreja Católica, o Governo Imperial e a sociedade brasileira do século XIX.

Percorrendo a biografia de Cândido Mendes, pretendemos analisar alguns traços da reforma ultramontana e do regalismo imperial nas relações entre a Igreja e o Estado na monarquia brasileira até 1881, ano de falecimento do nosso personagem. Sua vida pública foi testemunho de importantes fatos políticos e eclesiásticos, tais como: o regresso conservador; o controle do episcopado por parte dos ultramontanos; a tentativa de retomada de autoridade sobre a igreja no Brasil por parte da Santa Sé; os conflitos entre os dois poderes na década de 60 , envolvendo a questão matrimonial, as ordens religiosas, os benefícios eclesiásticos, a formação do clero; e o posterior acirramento desse conflito na Questão Religiosa e suas consequências.

Antes de terminar esta introdução, é necessário chamar a atenção do leitor para algumas escolhas metodológicas adotadas na elaboração deste texto e para o fato de este artigo não se constituir em uma produção de micro-história, pois o espaço dedicado a esse trabalho não permitiria desenvolver tal abordagem. Para que este trabalho pudesse ser caracterizado como uma abordagem de micro-história, teríamos de nos aventurar nos caminhos da antropologia, adentrando no sistema de crenças, de valores e de representações da época e dos locais em que viveu o nosso personagem. Exatamente devido às limitações inerentes a um artigo e ao estado 
Sobre esses personagens e sobre o ambiente cultural do Maranhão oitocentista os leitores interessados podem consultar: JANOTTI, Maria de Lourdes M. João Francisco Lisboa: jornalista e historiador. São Paulo: Ática, 1977 e BORRALHO, José Henrique de Paula. Um Athenas equinocial. São Luis: EDFUNC, 2010.

20

Gostaria de registrar aqui os meus agradecimentos a Joelma Santos da Silva, pela ajuda nas pesquisas realizadas em São Luís e pela sua leitura crítica do artigo, e a Liliane Faria Corrêa Pinto e a Professora Karla Martins (UFV), pela sua leitura crítica do artigo.

21

PASSARINHO, Jarbas. Apresentação. In: ALMEIDA, C. M. de. Pronunciamentos parlamentares 1871 a 1873 . Tomo I. Brasília: Senado Federal, Sociedade brasileira de Instrução, 1982, p. 19.

22

VILLAÇA, Antônio Carlos. O Senador Cândido Mendes. Rio de Janeiro: EDUCAM, 1981, p. 32.

23

SÁ VIANNA, Manuel Álvaro de Souza.

Comemoração do centenário natalício do Senador Cândido Mendes de Almeida (Elogio histórico lido na sessão do IHGB, de 14 de outubro de 1918). In: $R I H G B$, Rio de Janeiro, Imprensa Nacional, 1919, t. 83, p. 514.

24

SÁ VIANNA, Manuel Álvaro de Souza.

Comemoração do centenário natalício do Senador Cândido Mendes de Almeida (Elogio histórico lido na sessão do IHGB, de 14 de outubro de 1918). In: RIHGB, Rio de Janeiro, Imprensa Nacional, 1919, t. 83, p. 513-530.

25

VILLAÇA, Antônio Carlos. Op. Cit.

26

RODRIGUES J. H. Introdução. In: ALMEIDA,

Cândido Mendes de. Op. Cit. atual de nossas pesquisas, tivemos de realizar algumas escolhas, como, por exemplo, decidir tratar os antepassados diretos de Cândido Mendes e não os seus irmãos. Um deles foi João Mendes de Almeida, também político conservador e católico. Traçar paralelos com outros personagens contemporâneos a Cândido Mendes no Maranhão, como, por exemplo, João Francisco Lisboa e Francisco Sotero dos Reis ${ }^{19}$, também iria requerer uma quantidade de páginas que este tipo de trabalho não comporta ${ }^{20}$.

\section{2. À procura de Cândido Mendes de Almeida}

Poderíamos expor aqui uma série de descrições elogiosas a Cândido Mendes, que começaram a ser publicadas logo após sua morte. Todavia bastam poucas citações para que os leitores entendam os seus teores. Na apresentação dos Pronunciamentos parlamentares de Cândido Mendes, publicada pelo Senado Federal, o senador Jarbas Passarinho, em poucas palavras, buscou definir a essência da atuação política e judiciária de Cândido Mendes: um conservador por filiação partidária e que "teve, como poucos, a exata percepção do papel da Igreja, interpretando com acuidade incomum e profundidade histórica as relações entre ela e o Estado". Cândido Mendes também lutou pela emancipação dos escravos e por uma eficaz reorganização judiciária brasileira ${ }^{21}$.

Villaça daria a seguinte descrição sobre a atuação política de nosso personagem:

Cândido Mendes não foi um orador acadêmico que deleitasse e extasiasse, mas o orador parlamentar que convencia e sabia persuadir; faltava-Ihe a força da imaginação, que atrai e arrebata, mas sobrava-Ihe o poder da dialética, que vence e domina; não arrebicava frases, mas forjava razões maciças, argumentos fulminantes; às qualidades que podem iludir preferia a substância que é a própria realidade; nunca foi um político adaptável, mas um patriota sincero e independente.

Não podiam chamá-lo senão levianamente ou injustamente um intransigente, um retardatário, um retrógrado, porque era apenas um grande convencido, um circunspeto, o representante do espírito conservador, que parecia reacionário porque reagia ${ }^{22}$.

Manuel Álvaro de Sousa Sá Vianna, por sua vez, no seu Elogio Histórico de Cândido Mendes de Almeida, assim descreve a pessoa do senador Mendes:

Parece que o destino Ihe traçara uma vida modesta, tranquila e austera, sem choques violentos, nem saltos bruscos que muitas vezes levam às alturas, é certo, e não poucas abatem e prostram, predispondo-o assim a compreender praticamente essa grande verdade que nós bem sentimos e que um publicista francês reduziu a fórmula profundamente moral de que é só no dever que a felicidade se encontra ${ }^{23}$.

Todos os trabalhos sobre Cândido Mendes de Almeida até o momento publicados apresentam um homem sem fratura, integro, sem contradições, linear na sua conduta moral, política e intelectual. Todos foram produções encomendadas por ocasiões comemorativas, relembrando sua morte ou suas obras, ora pelo Instituto Histórico Geográfico Brasileiro ${ }^{24}$, no qual ingressou nos últimos anos de vida, ora por seus descendentes ${ }^{25}$, ora pelo Senado ${ }^{26}$.

Tais trabalhos, todavia, possuem muitas lacunas, demonstrando muito mais um intento laudatório que crítico. Não são uma produção biográfica problematizada. As principais lacunas se referem a seus ascendentes e à sua vida no Maranhão, que ocupam poucas linhas nas biografias. 
27

VILLAÇA, Antônio Carlos. Op. Cit. p. 21-23.
28

http://www.ibge.gov.br/cidadesat/historicos_ cidades/historico_conteudo.php?codmun=210210. Último acesso 06/08/2012.

29

SERRA, Astolfo. A Balaiada. Rio de Janeiro: Bedeschi, 1942

30

ASSUNÇÃO, Matthias Röhring. Balaiada e resistência camponesa no Maranhão (18381841). In: ZARTH, Márcia Motta Paulo. Formas de resistência camponesa: visibilidade e diversidade de conflitos ao longo da história. São Paulo: UNESP, 2001. p. 191-192.
Por isso, iremos começar tentando buscar as informações ou indícios que nos permitirão conhecer um Cândido Mendes diferente e, por meio dele, conhecer um período crucial da história do Brasil que vai da Independência ao Segundo Império.

\subsection{0 homem, seu tempo e sua obra}

Cândido Mendes de Almeida nasceu no dia 14 de outubro de 1818, em São Bernardo do Brejo dos Anapurus, Maranhão. Era filho de Fernando Mendes de Almeida, português, e Esméria Alves de Souza. Segundo Antônio Carlos Villaça, Cândido Mendes: "Nasceu numa freguesia humilde, numa vila, e lá passou a infância e a primeira juventude" ${ }^{27}$.

Normalmente é esta a visão inicial que é apresentada, ou seja, uma criança nascida em uma pequena e "humilde" freguesia do Maranhão, filho de um lusitano com uma filha da terra. Uma pessoa comum e nascida em um lugar de menor importância. Às vezes, seus biógrafos nos informam também o nome dos seus avós maternos: o Capitão-Mor Domingos Alves de Sousa e Euzébia da Conceição Alves de Sousa. Essa informação muda um pouco a situação precedente, ou seja, nosso biografado era filho de um oficial militar, um capitão-mor; era gente graúda.

Mas quem era esse casal? Infelizmente sobre o Capitão-Mor Domingos Alves de Sousa (1735-1801) não foi encontrada muita coisa até 0 momento. Mas o mesmo não se pode dizer de sua avó, Euzébia da Conceição Alves de Sousa (1745-1839). Dona Euzébia, segundo as várias histórias sobre a cidade do Brejo presentes em diferentes sites, oficiais ou não, foi a povoadora por excelência do povoado onde nasceu Cândido. Mulher de caráter forte, que comandou a região com punhos de ferro e morreu durante a revolta regencial conhecida como Balaiada. Segundo o site do IBGE:

Em 1729, Brejo era ainda um sítio que, a 11 de julho desse ano, foi doado a Francisco Vasconcelos seu primeiro povoador efetivo. Entretanto, a principal povoadora foi a portuguesa Euzébia Maria da Conceição, possuidora de grande fortuna e de muitos escravos que, acompanhada de seus colonos, chegou à localidade, em data desconhecida. Mais tarde, foi vitimada por ocasião da guerra da Balaiada, que causou graves prejuizos econômicos e sociais a Brejo. Segundo o historiador Astolfo Serra, Brejo foi o último reduto dos balaios, finalmente vencido em dezembro de $1840^{28}$.

Nosso personagem começa a criar contornos mais complexos: neto de um capitão-mor que faleceu em 1801 e cuja avó se transferiu de Portugal para o Brasil juntamente com a família real em 1808. Euzébia não era uma pessoa qualquer, nem mesmo pobre, pois, comandando escravos e colonos, foi povoar a região do Brejo. Cândido Mendes provinha de uma família de importância política e econômica no Maranhão. Era membro dos potentados locais, em uma cidade que, mesmo sendo humilde, possuía um posicionamento estratégico, pois fora disputada ferozmente durante a Balaiada, sendo o último local a ser pacificado ${ }^{29}$.

Matthias Röhrig Assunção, em dois artigos publicados recentemente (2008 e 2010), nos dá algumas importantes informações sobre a avó de Cândido Mendes de Almeida. Esse historiador confirma as informações precedentes e ainda nos fornece vários outros detalhes sobre como Dona Euzébia comandava com punhos fortes, usando de violência contra escravos e rebeldes. Aos escravos quilombolas, o castigo era a morte e depois Ihes "esticava o couro"; aos rebeldes Ihes mandava bala e depois Ihes pisava a cabeça ${ }^{30}$. 
31

Januária "Patrício" Ferreira da Costa, 82 anos em 1982, Almas, município do Brejo. Apud ASSUNÇÃO, Mathias Röhring. Op. Cit. p. 191-192.

32

AMARAL, José Ribeiro do. Apontamentos para a história da Revolução da Balaiada na Província do Maranhão. Vol. 2. São Luis: Tip. Alfaiatari Teixeira, 1898-1906. p. 26

33

O Legalista, 1840, n. 35. p. 1.

34

BARATA, Carlos Eduardo Almeida. Dicionário das familias brasileiras. São Paulo: Nova Página, 1999.

35

SILVA, Luis Antônio Vieira da. História da Independência da Província do Maranhão 18221828. Edição comemorativa ao Sesquicentenário da Independência do Brasil. 2. ed. Rio de Janeiro: Companhia Editora Americana, 1972. p. 118 e 136

36

COUTINHO, Milson. Caxias das Aldeias Altas: subsídio para sua história. São Luís: Prefeitura de Caxias, 2005, p. 305.

37

BOTELHO, Joan. Conhecendo e debatendo a história do Maranhão. São Luis: Fort Gráfica, 2007. p. 97-98.

\section{8}

OTÁVIO, Rodrigo. A Balaiada 1839. São Paulo: Editora Siciliano, 2001; BORRALHO, José Henrique de Paulo. A Athenas equinocial, a fundação de um Maranhão no Império brasileiro. Tese (Doutorado em História Social). 2009. Faculdade Federal Fluminense, Niterói, p. 124. 2009.
Como nos informa Assunção, com a mesma violência que comandou foi morta durante a Balaiada. 0 leitor deve estar ciente de que a violência era um ato corriqueiro na sociedade daquela época. Segundo ele, ela foi:

barbaramente morta, com 21 facadas, ... pelo balaio Antônio Bem-te-vi, que com mais de nove companheiros, depois de deceparem-Ihe a mão direita, trouxeram-na em troféu pelas ruas da vila além de roubarem suas joias e Rs $1.200 \$ 000$ em moedas de ouro.

Segundo a memória oral, menos puritana que as enciclopédias, não foi bem a mão que levaram em troféu para o Brejo, mas as partes genitais: "A Euzeba Maria: Era chamada de Dona Cabana. Esticaram a coisa dela pro Severino olhar" ${ }^{\prime \prime}$.

Outra fonte relata que Euzébia Maria já teria mais de oitenta anos na ocasião, e lhe cortaram uma orelha e uma das mãos para levá-las a seu filho que era capitão-mor ${ }^{32}$. Sabemos então que a avó de Cândido Mendes foi brutalmente assassinada durante a Balaiada, em 1839, ano em que ele voltava ao Maranhão, depois de quatro anos estudando Direito na faculdade de Olinda.

Seu pai faleceu no ano seguinte, em $1840^{33}$. Não encontramos muitas informações sobre ele. Segundo o Dicionário das Famílias Brasileiras de Carlos Eduardo de Almeida Barata, o Capitão Fernando Mendes de Almeida foi batizado em 9 de julho de 1798, na freguesia Fornotelheiro, Celorico da Beira, Guarda, Portugal, e faleceu em 20 setembro de 1840 no Maranhão. Em 1816, transferiu-se para o Brasil, estabelecendo-se na cidade de Caxias, Maranhão. Casou-se, em 1817, com Esméria Alves de Souza, nascida por volta de 1800 e falecida em $1 .^{\circ}$ de março de 1881, em São Paulo ${ }^{34}$.

Na história do Maranhão, existem alguns relatos sobre a participação do tenente Fernando na Guerra de Independência. Nessa província, esse processo foi sangrento e conturbado, devido à sua forte ligação com Portugal. 0 tenente Fernando lutou contra a independência, em favor dos portugueses que apoiavam as cortes de Lisboa contra D. Pedro I. Ele combateu na cidade do Brejo e na vila do Rosário contra as tropas independentistas que vinham do Piaui e do Ceará35. As divisões entre as elites locais durante a Guerra de Independência perduraram nas décadas posteriores, e muitos portugueses foram constantemente perseguidos; esse foi o caso de Fernando Mendes de Almeida. Politicamente, ele se posicionou ao lado dos conservadores, conhecidos como cabanos, contra os liberais, conhecidos como bem-te-vis.

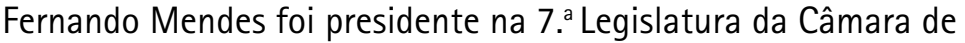
Caxias (1830-1833) ${ }^{36}$. Em 1831, ocorreu uma revolta no Maranhão, que ficou conhecida como Setembrada. Nesse conflito, Fernando combateu ao lado dos cabanos. Seu nome constava entre os que deveriam ser expulsos da província, em uma representação dos revoltosos ao governo provincial ${ }^{37}$. $\mathrm{Na}$ guerra que estourou no Maranhão entre os anos de 1838 e 1841, conhecida como Balaiada, Fernando Mendes de Almeida, já idoso, novamente se envolveu no conflito ao lado dos conservadores, chefiando as guarnições de Caxias contra os balaios, sendo, inclusive, aprisionado pelos rebeldes ${ }^{38}$.

Voltemos ao nosso personagem e reformulemos as informações sobre suas origens. Cândido Mendes de Almeida provinha de uma rica e importante família do Maranhão; seu avô materno e seu pai pertenciam às elites militares do reino português. Seu pai lutou ao lado dos portugueses contra a independência do Brasil e, posteriormente, ao lado dos cabanos conservadores, tanto na Setembrada (1831) quanto na Balaiada (1838-1841). Sua 
39

As informações sobre a formação de Cândido Mendes antes de ir para Olinda divergem entre os seus biógrafos. Alguns indicam que ele estudou no Brejo, outros em Caxias, e outras ainda em São Luis. Em 1830, a familia Mendes de Almeida morava em Caxias, pois lá nasceu João, irmão de Cândido Mendes. Tal fato nos levou a dar crédito a um manuscrito de José Carlos Rodrigues, amigo de Cândido, que traz as informações dadas acima, no corpo do texto. RODRIGUES, José Carlos. Notas biográficas sobre Cândido Mendes de Almeida. Biblioteca Nacional, Sessão Manuscritos, I-03,16,041.

40

SÁ VIANNA, Manuel Álvaro de Souza. Op. Cit. p. 515.

41

VILLAÇA, Antônio Carlos. Op. Cit. p. 23.

42

SANTIROCCHI, Ítalo Domingos. Os ultramontanos no Brasil. Op. Cit.

43

WERNET, Augustin. Op. Cit. p. 115-131.

44

VIEIRA, Dilermando Ramos. Op. Cit.

45

VILLAÇA, Antônio Carlos. Op. Cit. p. 26.

46

NESTOR, Odilon. Faculdade de Direito do Recife, traços de sua história. Recife: Imprensa Industrial, 1931. p. 57. avó materna foi uma das colonizadoras do lugarejo chamado Brejo, localidade que desempenhou um papel estratégico na Balaiada. Euzébia era uma rica matriarca, com fortuna, terras, escravos e poder político. Ao combater os Bem-te-vis em 1839, foi brutalmente assassinada pelos seus inimigos que, por sua vez se vingavam das atrocidades cometidas pela própria Dona Euzébia. Foi nesse ambiente de colonização, mandonismo, escravidão, antilusitanismo, disputas e revoltas sangrentas que nasceu, cresceu e se formou em primeiras letras Cândido Mendes de Almeida.

Cândido Mendes estudou as primeiras letras e um pouco de latim em Caxias. A preparação para a Faculdade de Direito ele fez em São Luís ${ }^{39}$. Em 1835, transferiu-se para Olinda a fim de cursar Direito e lá restou até 1839, quando voltou para o Maranhão. Os seus dois primeiros anos, após seu retorno, devem ter sido traumáticos, devido à brutal morte de sua avó e à perda de seu pai. Todavia voltemos nossa atenção à sua formação acadêmica. Na faculdade de Direito em Olinda, foi contemporâneo de importantes personagens do Império, como Carvalho Moreira, o futuro Barão do Penedo, Herculano de Sousa Bandeira, Teixeira de Freitas, Francisco José Furtado, Fábio Alexandrino de Carvalho Reis ${ }^{40}$.

A Faculdade de Direito de Olinda, naqueles anos, funcionava no claustro de São Bento, onde Cândido Mendes teve oportunidade de conviver com os monges, vivenciando um pouco da vida monástica, mas também da decadência das ordens religiosas ditas brasileiras, ou seja, aquelas que sobreviveram ao Período Colonial. Villaça diz que essa influência iria marcar o destino do nosso personagem: "0 seu destino será um tanto monástico, afinal, pela austeridade singela, pelo gosto religioso do estudo, pelo devotio crescente, pela intimidade com os temas teológicos, pela participação litúrgica"41.

Não se pode negar que essas características vão se desenvolver em Cândido Mendes, porém é difícil imaginar que as tenha adquirido em um mosteiro onde reinava um espirito laxista, o apego às riquezas e aos bens materiais, onde as regras da ordem eram constantemente desrespeitadas e muitos monges tinham uma conduta moral duvidosa. A decadência da ordem foi relatada em vários documentos dos bispos, encarregados pontifícios e governos provinciais ${ }^{42}$ e descritos por grandes historiadores do tema, como Augustin Wernet ${ }^{43}$ e Dilermando Ramos Vieira ${ }^{44}$, que também fazem questão de ressaltar que a situação dos beneditinos ainda era um pouco melhor que a das demais ordens. Todavia, deve-se considerar a possibilidade de que 0 convivio com um ambiente pouco rigoroso possa ter tido um efeito inverso em Cândido Mendes, fortalecendo, como reação, a sua ortodoxia.

A Faculdade de Olinda formava a elite brasileira nos moldes da reformada Universidade de Coimbra e os beneditinos já tinham sido influenciados pelas "luzes" desde o periodo pombalino. A visão dessa faculdade sobre a relação entre o poder espiritual e o secular era impregnada de regalismo. A Igreja era vista como um sustentáculo do Trono e os eclesiásticos como funcionários públicos ao serviço do Estado. Segundo Villaça: "quanto às ideias, Olinda ainda era uma projeção ou uma representação do ensino coimbrense"45. Já segundo Odilon Nestor, na Faculdade de Olinda não se presenciava "nenhuma exteriorização comum de sentimentos religiosos", o que só iria acontecer com sua transferência para o Recife ${ }^{46}$.

Aos 21 anos de idade, em 1839, Cândido Mendes se formou em Ciências Jurídicas e Sociais. Logo iniciou o exercício da advocacia. Eram anos de instabilidade, que forçaram o amadurecimento do jovem advogado ao ver 
47

SÁ VIANNA, Manuel Álvaro de Souza. Op. Cit. p. 516.

48

VILLAÇA, Antônio Carlos. Op. Cit. p. 27.

49

NOGUEIRA, Octaviano e FRIMO, João Sereno. Os parlamentares do Império. Brasília: Senado Federal, 1973. p. 46.

50

Observador, n. 1, 1847

SOUZA, Lucimar Carvalho. Os pasquins em São Luis na primeira metade do século XIX. 2006. Dissertação (Pós-Graduação lato Sensu em História do Maranhão). Universidade Estadual do Maranhão, São Luis, 2006, p. 30 e 40-43. seu estado, o Maranhão, tomado pela guerra civil. Como vimos, nesses anos de angústia, ele perdeu violentamente sua avó materna (1839) e posteriormente seu pai (1840), tornando-se, então, o chefe da família aos 22 anos de idade, tendo de manter sua mãe e seus três irmãos mais jovens.

Em 1840, superou o concurso para lecionar no Liceu do Maranhão, na cadeira de História e Geografia, onde já era mestre Sotero do Reis. Foi contemporaneamente promotor público em São Luís entre 1841 a 1842. Logo, iniciou a carreira política ao se eleger como suplente de Manuel Jansen Pereira. Cândido acabou substituindo-o e foi deputado pelo Partido Conservador na quinta legislatura (1843-1844) ${ }^{47}$ (Sá Viana, 1918: 516). Segundo Villaça, "como político visitou o interior do Ceará, do Piauí, de Goiás. Viu de perto a situação real dos conterrâneos. Observava, anotava. Não era, nunca foi, um divagador. Era um realista" ${ }^{48}$. Foi deputado nas legislaturas: 5. a (1843-1844), 8. ${ }^{a}$ (1850-1852), 9. ${ }^{a}(1853-1856), 10 .^{a}(1857-1860)$ e $14 .^{a}$ (1869-1871). Exerceu também as funções de Secretário da Província do Maranhão (1849-1854), Diretor de Seção da Justiça (1954-1857) e Chefe da Seção da Secretaria dos Negócios do Império (1860-1864)49.

No entanto, antes de adentrar na sua carreira política, seria interessante conhecer um pouco do Cândido Mendes jovem jornalista e sua vida no Maranhão. Nesse período, também existem muitas lacunas nas biografias do nosso personagem. Elas relatam que foi no ano de 1842 que Cândido Mendes iniciou a demonstrar os seus dotes jornalísticos ao fundar o seu primeiro jornal: A opinião Maranhense, seguido pelo primeiro jornal de Caxias, o Brado de Caxias: throno e liberdade, em 1845. Em 1847 criou o Observador, em São Luis, que sobreviveu até 1861. Esse jornal era o representante dos Saquaremas, ou Conservadores ${ }^{50}$. Em 1843, publicou seu primeiro opúsculo: As eleições das Províncias do Maranhão. Estranhamente o seu jornal 0 Legalista e um pasquim que se suspeita ser seu, 0 picapa $0^{51}$, não são referidos nas suas biografias. 0 motivo mais provável dessa omissão talvez seja o fato de 0 picapao não ser assinado, porém o mesmo não se pode dizer de 0 Legalista já em circulação em 1840 e em constante conflito com seus opositores bem-te-vis.

Pelas informações aqui presentes, sabemos que Cândido Mendes dividia sua vida entre o magistério, a promotoria e o jornalismo. Até 0 momento, não temos traços do seu catolicismo, nem mesmo do seu caráter, para confirmar ou desmentir a imagem de um homem que sempre se manteve constante em sua personalidade. Seria interessante conhecer esse jovem, saber como se relacionava com os potentados locais, já que se ocupava de assuntos que os tocavam de perto. Não podemos esquecer que o próprio Cândido Mendes pertencia a esses potentados e, provavelmente, era uma das lideranças de sua família, já que havia perdido a grande matriarca e o seu pai.

Pesquisando sobre a imprensa no Maranhão, é possivel encontrar indícios da vida do jovem Cândido, ou melhor, jovem e intrépido. Descobre-se que Cândido Mendes atuou intensamente no jornalismo polêmico por meio dos pasquins, onde os potentados trocavam insultos e acusações. Por seu caráter difamatório, o leitor deve encarar as informações que serão aqui apresentadas com senso crítico, pois são exageradas ou até mesmo falsas, porém ajudam a compreender o clima e o ambiente nos quais estava inserido o nosso personagem.

No artigo do Jornalista Sebastião Jorge, $A$ Censura na Imprensa do Maranhão, encontramos uma primeira pista sobre o jovem Cândido. 
JORGE, Sebastião Barros. A censura na imprensa do Maranhão. Revista Cambiassu. São Luis: UFMA, n.2, jan./dez. 2006. p. 81

Idem. p. 53.

54

Idem. p. 82

55

VILLAÇA, Antônio Carlos. Op. Cit. p. 29.
Segundo o artigo, ele movia, no jornal 0 legalista, 1840, uma campanha contra a família de Ana Jansen, conhecida também como "Rainha do Maranhão", mulher rica e poderosa, a quem se atribuem muitas maldades a escravos e aos inimigos políticos. Segundo Jorge, Cândido Mendes foi desafiado pelo filho de Ana Jansen, IzidoroJansen Pereira (Coronel e Comandante da Guarda Nacional), para um duelo à bala. Demonstrando coragem, nosso personagem se apresentou no local e no horário estabelecidos para o duelo, no entanto, seu adversário não compareceu, enviando um recado dizendo que tudo não passava de um deboche: "Diga a ele que o duelo será a cacete, numa outra oportunidade" ${ }^{25}$.

0 "cacete" realmente aconteceu, mas não foi um duelo! Quem deu o "cacete" foi o pai de IzidoroJansen, o Izidoro Rodrigues. Jorge assim nos narra o ocorrido:

\begin{abstract}
A temperatura do caldeirão político chegou a um clima de tão gravidade que Cândido Mendes terminou sendo esbofeteado em pleno teatro São Luis, hoje Artur Azevedo, pelo coronel Izidoro Rodrigues Pereira, marido de Ana Jansen. 0 caso se transformou em um escândalo. A cidade se dividiu entre os que riram, por vingança e deboche, sentindo prazer com a cena e os que olharam com revolta os gestos de truculência. De qualquer jeito eram as regras do jogo $0^{53}$.
\end{abstract}

Cândido Mendes foi surrado, provavelmente por causa dos insultos e difamações que publicava no Picapao contra Izidoro Rodrigues e sua mulher Ana Jansen. Nos pasquins de seus inimigos, Cândido também foi difamado. Recebeu dois apelidos principais: "Cão Mendes" e "Dr. Cara Pelada". Porém os insultos mais graves apareceram no jornal O Guajajara da familia Jansen, onde a masculinidade do jovem Cândido foi colocada em dúvida e ele foi acusado de promiscuidade com caixeiros e escravos. Pode-se ver que não era fácil a vida em província, principalmente para um jovem pertencente aos potentados e que queria desafiar seus adversários no poder. Apesar de demonstrar coragem e intrepidez, Cândido Mendes foi também humilhado, com difamações e surra pública. Para completar, perdeu o seu cargo de promotor ${ }^{54}$. Essa imagem de Cândido Mendes difere muito do homem disciplinado, recluso, sem arrebates que nos descrevem as biografias, que se centram muito mais na sua vida adulta. Quais motivações transformaram Cândido Mendes num exemplo de moral, inteligência e ortodoxia católica? Essa não é uma pergunta fácil de responder, pois muitas lacunas ainda restam.

Segundo Villaça, Cândido Mendes era um estudioso por vocação, se entregava totalmente a suas pesquisas e à elaboração dos seus textos. Era apaixonado pela busca de documentos e compilação dos mesmos em obras monumentais. Isso era possivel graças à sua ferrenha disciplina. Segundo esse autor, ele se entregava de forma religiosa ao seu trabalho:

\footnotetext{
Foi um homem de estudo. Não era dado aos prazeres mundanos. Ninguém o via em festas, em dissipações, em divertimento. Vivia para os livros. Estava sempre em casa, lendo, escrevendo, pesquisando. Conheceu os problemas do povo. Participou intensamente, dramaticamente das lutas políticas da sua Província (...) Mas sempre na perspectiva que lhe era própria, a do professor, a do pesquisador. (...) A defesa dos autênticos interesses populares era sua linha inflexivel, invariável ${ }^{55}$.
}

Algumas das características aqui apresentadas podem ser colocadas em dúvida por meio dos dados anteriormente apresentados, que demons- 
tram uma vida social e politicamente ativa, defendendo muitas vezes os interesses familiares ou partidários, mais do que aqueles do "povo". Aliás, como conhecer "os problemas do povo" quando se "vivia para os livros"? No entanto, ele fornece $o$ indício de sua participação ativa nas dramáticas "lutas políticas de sua Província". Descrições como essas parecem exageradamente laudatórias e, evidentemente, elaboradas para a construção da memória, dificultando um contato mais aproximado com a personalidade e a vida do nosso personagem.

Todavia, uma coisa não se pode negar. Com certeza, Cândido era um amante dos estudos e, pela sua grande produção, pelo nivel de erudição, pela paixão pelos documentos, seguramente tinha uma disciplina incomum! Pois, além das produções jurídicas, históricas, geográficas e jornalisticas, ainda participava ativamente da política do seu tempo. Falando em política, é irônico como Cândido Mendes chegou à Câmara dos Deputados, substituindo seu inimigo político, um Jansen, em 1844.

0 contato com a corte lhe abriu diversas portas e várias possibilidades de crescimento no meio político e administrativo. Ele tinha tudo para conseguir tal sucesso: membro das oligarquias locais, com grande capacidade intelectual e era um conservador chegando ao governo bem no momento em que estava em ato o movimento político conhecido como Regresso Conservador, que buscava fortalecer o poder central do Imperador, pacificar o pais e realizar uma reforma na Igreja Católica, por meio de nomeações de ultramontanos para as cadeiras episcopais. 0 momento não podia ser melhor para Cândido Mendes. Já podemos vislumbrar o Cândido Mendes defensor da ordem e da Constituição!

Com certeza, as instabilidades politicas da sua província the deixaram cicatrizes doloridas, que, juntamente com a tradicional posição conservadora de sua familia, Ihe moldaram o caráter. A formação jurídica e sua paixão pelos estudos the forneceram os instrumentos para defender suas opiniões. Os jornais e funções públicas Ihe deram mais força politica. Porém, ainda falta um ingrediente. Até esse momento, não foram encontradas referências ao seu catolicismo.

Não é fácil, consultando a biografia e a documentação disponivel no momento, indicar quando Cândido Mendes de Almeida despertou seu lado católico convicto, isso se houve um despertar, pois existe a possibilidade de que essa convicção Ihe tenha sido transmitida no seio familiar e nunca o tenha abandonado. Mesmo assim, é difícil imaginar que uma família no interior do Maranhão, já em 1818, alimentasse um catolicismo tão ortodoxo e tão alinhado com as diretrizes romanas como aquele que marcou a vida do Cândido Mendes adulto.

0 mais provável é que ele tenha recebido, na sua formação familiar, o catolicismo chamado de "tradicional", ou seja, aquele que se praticava em Portugal, no Brasil Colonial e em boa parte do Período Imperial. A aproximação com a ortodoxia provavelmente tenha acontecido durante a sua formação jurídica, não devido à proximidade com os beneditinos como indicado por Villaça, mas sim pelo amor e respeito às leis, que se juntavam à disciplina do caráter do jovem advogado.

Segundo Villaça, o recolhimento de nosso personagem se pronunciou "ainda mais" após o seu casamento com Rosalina Ribeiro Campos. 0 matrimônio se realizou no Rio de Janeiro em 20 de setembro de 1850, quando Cândido Mendes já contava com quase trinta e dois anos de idade. 0 casal se fixou na Corte em 1854, e em 1857 nasceu o seu primeiro filho, 
56

VILLAÇA, Antônio Carlos. Op. Cit. p. 30.
57

SANTIROCCHI, İtalo Domingos. Os ultramontanos no Brasil. Op. Cit.; SILVA, Joelma Santos da. Por Mercê de Deus, a Igreja e a Política na trajetória de Dom Marcos Antônio de Sousa (1820-1842). Dissertação (Mestrado em Ciências Sociais). 2012. Centro de Ciências Humanas da Universidade Federal do Maranhão: São Luís. 2012.
Fernando. Rosalina era uma mulher marcadamente católica, influenciando decisivamente a já forte espiritualidade do marido. Segundo Villaça, após o casamento, a religiosidade de Cândido Mendes "se tornou mais profunda, mais densa, mais intensa, mais coerente"; e seu catolicismo "será mais absorvente, mais exigente, mais absoluto" ${ }^{56}$.

Não encontramos informações sobre Rosalina, porém, sua influência sobre Cândido Mendes parece evidente. 0 próprio percurso de vida de nosso personagem talvez favoreça isso. Sem pretender psicanalisá-lo, provavelmente as mulheres tiveram uma influência muito marcante sobre a sua personalidade. Sua avó era uma mulher forte e poderosa, e também o era sua principal adversária política no Maranhão, Ana Jansen. Tal fato pode ter favorecido a influência da esposa na sua personalidade.

A vida familiar, a espiritualidade da esposa, o respeito pela ordem e pela Constituição, tudo isso o levou ao respeito à Religião oficial, não desconsiderando que o contrário também possa ser verdadeiro. Ao se entregar às pesquisas jurídicas, não estudou somente as constituições e leis civis, mas também as eclesiásticas, tomando conhecimento dos direitos e deveres das respectivas instituições. No entanto, a partir de determinado momento, Cândido Mendes passou a se considerar primeiro católico e depois brasileiro, como irá afirmar algumas vezes no Senado.

0 que se pode comprovar é que seu primeiro escrito de cunho religioso foi realizado em 1856, dois anos após o matrimônio, o que corrobora a teoria de Villaça. Nesse ano, publicou as traduções da Instrução sinodal de monsenhor Pie, atual bispo de Poitiers sobre os principais erros do tempo presente e dos Sentimentos de Napoleão Bonaparte sobre o Cristianismo. Em 1860, traduziu mais duas obras: Pio IX e a França em 1849 a 1859, pelo Conde de Montalembert, traduzido em vulgar da segunda edição em Paris e O Papa. Questões na ordem do dia, por monsenhor de Segur.

Todavia vem à mente a seguinte pergunta: será que o leitor está convencido? Nós não estamos. Não temos provas da força da influência familiar no seu catolicismo. Não podemos garantir a influência dos beneditinos. É muito provável que Villaça tenha razão a respeito da influência de Rosalina sobre a espiritualidade de Cândido, mas será que ela já possuía um catolicismo ortodoxo nessa época? Com a reforma ultramontana ainda no seu início? Deve ter algo mais. Uma figura religiosa que seja marcante, que possa influenciar uma pessoa com a personalidade de Cândido. Alguém que tenha marcado época, que tenha feito história, que tenha tido proximidade com nosso personagem e que fosse um católico ortodoxo ou próximo disso. Só um nome me vem à mente, e talvez também já tenha vindo à mente dos leitores mais informados sobre a Igreja ou sobre o Maranhão do século XIX. Referimo-nos a Dom Marcos Antônio de Sousa, bispo do Maranhão entre os anos de 1826 e 1842 .

D. Marcos, como deputado nas Cortes de Lisboa, teve participação ativa na independência e foi deputado na legislatura de 1826. Era um constitucionalista, porém conservador. Juntamente com D. Santíssima Trindade de Minas Gerais e D. Romualdo de Seixas, arcebispo da Bahia, D. Marcos foi um dos precursores do ultramontanismo no Brasil. Apesar de ainda estarem ligados a algumas práticas tradicionais do catolicismo lusitano e serem extremamente fiéis ao trono (o mesmo talvez não se possa dizer de Santíssima Trindade), eles eram o exemplo da ortodoxia naqueles anos: fiéis ao papa, fiéis às determinações do Concílio de Trento e defensores da autonomia da Igreja perante o Estado ${ }^{57}$. 
58

O Legalista, n. 26 e 28,1840

59

SANTIROCCHI, İtalo Domingos. Os ultramontanos no Brasil. Op. Cit.

VILLAÇA, Antônio Carlos. Op. Cit. p. 40.

61

RODRIGUES J. H. Op. Cit.
Raciocinemos juntos. Cândido Mendes, membro de importante família do Maranhão, participante ativo da política provincial, professor, advogado, promotor em São Luís e ainda por cima conservador. Teria como esses dois personagens não terem tido contato? Parece-me impossivel. E o contato com um bispo como D. Marcos com certeza teria a força para imprimir a ortodoxia católica em Cândido Mendes, ou pelo menos preparar o seu espírito para ela.

Lendo um dos seus jornais, $O$ Legalista, essa influência pode ser percebida. No ano de 1840, foi publicado na íntegra um discurso de D. Marcos na Assembleia Provincial em defesa da fundação do Seminário Diocesano, o Seminário Santo Antônio. Não se publica um discurso de um bispo e se defende um projeto de construção de um Seminário à toa. Eles pertenciam ao mesmo grupo político, e provavelmente tinham contato pessoal, e Cândido Mendes muito possivelmente foi influenciado por esse personagem marcante ${ }^{58}$.

Agora sim temos um forte indício sobre a proveniência de sua ortodoxia. Se ligarmos isso à sua chegada ao Rio como deputado em pleno Regresso Conservador, coincidindo com o início da Reforma Ultramontana sistemática, com bispos marcantes como D. Antônio Viçoso em Minas e D. Antônio de Mello em São Paulo, e ao aumento da autoridade pontifícia no Brasil, com o envio de Internúncios Apostólicos para o Rio de Janeiro, após praticamente 10 anos de representação nas mãos de um Encarregado de Negócios, o quadro fica mais claro ${ }^{59}$.

Seu catolicismo e, principalmente, o seu ultramontanismo aparecem claramente na sua maior obra, o Direito Civil Eclesiástico Brasileiro antigo e moderno, em suas relações com o Direito Canônico, publicada em dois volumes, em 1866 e em 1873. Uma verdadeira obra-prima juridica e histórica a respeito das relações da legislação civil e sobre a Igreja e suas contradições em relação ao Direito Canônico. Nesse livro, a ortodoxia e o ultramontanismo de Cândido Mendes já se encontram maduros e totalmente elaborados. Dessa importante obra é que ele irá tirar a erudição para seus discursos em defesa das ordens religiosas em 1869 e dos bispos na Questão Religiosa nos anos setenta.

A partir desse momento, o seu catolicismo passou a causar admiração a todos: políticos, padres, bispos e aos representantes da Santa Sé no Brasil, os Internúncios Apostólicos, que encontraram nele um fiel aliado. Durante o Segundo Império, nenhum leigo foi tão fortemente ligado ao centro do catolicismo e à ortodoxia quanto Cândido Mendes. Segundo Villaça: "Ele defendia a religião católica numa dupla perspectiva - porque era a sua religião pessoal e porque, por força da Constituição, continuava a ser a religião do Estado. Como cidadão, como jurista, como político e como católico, defendia a religião católica"60.

Em 13 de maio de 1871, Cândido Mendes foi eleito Senador do Império, tomando assento em 19 de maio. A partir dessa data, lutará principalmente por duas causas: a da abolição, ou seja, a luta parlamentar em defesa da Lei do Ventre Livre, logo em 1871, e a Questão Religiosa, em 1873 , isto é, a batalha contra a maçonaria e o regalismo em defesa da liberdade da Igreja. É na cadeira do Senado que pronunciará dois discursos de incrivel erudição histórica, jurídica e teológica, que ficaram na memória dessa instituição: o de 10 de março e o de 30 de junho de $1873^{61}$.

$\mathrm{Na}$ Corte, enquanto era deputado e senador, continuou a sua carreira de jornalista, redigindo o Correio da Tarde, escrevendo no Sentinela da 
62

VILLAÇA, Antônio Carlos. Op. Cit., p. 30-31 e 35; SÁ VIANNA, Manuel Álvaro de Souza. 0p. Cit. p. 547-548.

63

VILLAÇA, Antônio Carlos. Op. Cit. p. 34.

64

BLAKE, A. V. A. Sacramento. Dicionário bibliográfico brasileiro. Vol. 2, Rio de Janeiro: Imprensa Nacional, 1883-1902, p. 35-40.

65

ABREU, J. Capistrano de. Ensaios e Estudos (Crítica e História). Edições da Sociedade Capistrano de Abreu, Livraria Briguiet, 1931. p. 197.

66

VILLAÇA, Antônio Carlos. Op. Cit. p. 63, 66.
Monarquia, no Brasil, no Correio Mercantil. Além de político e jornalista, dedicou-se à literatura, à geografia e à história. Nos anos 50 , publicou dois trabalhos que chamaram a atenção de Varnhagen para o seu nome. 0 Tury-assù ou a incorporação d'este território à Província do Maranhão (1851) e A Carolina, ou a definitiva fixação de limites entre as províncias do Maranhão e de Goyas (1852). Essas obras começam a abrir-Ihe as portas do Instituto Histórico e Geográfico Brasileiro e demonstraram a sua capacidade e gênio, trazendo de volta ao Maranhão dois territórios que havia décadas estavam em disputa com o Pará e o Goiás. Em 1860, publicou o seu primeiro grande livro, Memórias para o Extinto Estado do Maranhão, que só seria concluido quatorze anos depois, em 1874, com o segundo tomo ${ }^{62}$.

Seu nome já havia sido proposto ao Instituto Histórico desde 1853, por sugestão de Varnhagen a Pedro II, mas só em 25 de setembro de 1868, o sócio Pedro Torquato Xavier de Brito o indicou oficialmente. Nesse ano, havia publicado o Atlas do Império do Brasil, que causou impressão entre os membros do IHGB. Mas, somente dez anos depois, em 1878, seria distinguido com a condição de sócio honorário. Essa demora em ingressar na instituição era o resultado do seu posicionamento político a favor da Igreja, contrariando o Imperador, importantes políticos e intelectuais da época ${ }^{63}$.

Em 1869, publicou o Código Filipino, com 1.487 páginas, juntamente com o Auxiliar Jurídico, com 849 páginas. Em 1874, publicou os Princípios de Direito Mercantil, reedição da obra do Visconde de Cairu. Outras obras de Cândido Mendes de Almeida que merecem ser citadas são: Discurso combatendo a medida de venda dos bens das corporações monásticas, e a conversão do respectivo produto em apólices da dívida pública, Rio de Janeiro, 1869; Discurso pronunciado no Supremo Tribunal de Justiça na sessão de 21 de fevereiro de 1874 por ocasião do julgamento do exmo. e revmo. Sr. Bispo de Olinda, Rio de Janeiro, 1874; e Instrução sinodal de monsenhor Pie, atual bispo de Poitiers sobre os principais erros do tempo presente, tradução, publicado no Correio da Tarde $1856^{64}$.

Ainda esquecido pelos atuais estudos de Historiografia e Teoria da História, há de se lembrar que Cândido Mendes foi um dos grandes nomes da produção historiográfica brasileira do século XIX, rivalizando com Varhagem. Causou admiração a Capistrano de Abreu que, na primeira série dos Ensaios e Estudos, assim se referia ao nosso personagem: "Tomava um dos pontos que the parecia obscuro e cavava-o, circunvalava-o e descobria um tesouro. Dessa investigação, esfuziavam fagulhas, que iluminavam as adjacências". Capistrano defende que somente ele pode ser comparado a Varnhagen ${ }^{65}$.

Já Villaça assim se refere ao Cândido Mendes historiador: "Foi um pesquisador preocupado com as fontes, com a compilação dos documentos. Quis oferecer-nos concretamente e exaustivamente a reprodução das fontes, tudo interpretado meticulosamente pelo seu espírito investigador". Esse autor distinguiu os traços da fé de Cândido Mendes até mesmo na produção histórica e geográfica, ao ressaltar que havia na sua vida uma procura de Deus através da sua "busca incessante da verdade", por este motivo coletava dados históricos, topográficos, estatísticos, astronômicos, e elaborava suas obras ${ }^{66}$.

No dia 4 de janeiro de 1881, realizou sua última fala no Senado, pois faleceu no primeiro dia de março. Quarenta e duas horas antes, na manhã de domingo de 27 de fevereiro, enquanto se dirigia à Igreja do Santíssimo Sacramento para assistir à missa das sete horas, acompanhado pelo seu segundo filho, Cândido de quinze anos, sentiu-se mal e iniciou sua ago- 
67

Idem. p. 55.

68

Idem. p. 56.

69

Original: La difesa degli interessi Cattolici in questo Impero soffri una perdita sensibilissima il $1^{\circ}$ del corrente mese colla morte del Senatore Candido Mendes de Almeida. Una congestione cerebrale, che gli tolse immediatamente l'uso delle facoltà mentali, lo porto all'altra vita nell'età di 60 anni circa. Egli era uomo molto erudito, schiettamente cattolico, conoscitore e sostenitore infaticabile del diritto canonico, nemico dichiarato dei placet, degli exequatur e del regalismo; sempre il primo a parlare, protestare, e fare quanto era in suo potere per difendere Religione, Chiesa, S. Sede e Clero per lo spazio di circa 20 anni sia nella Camera dei Deputati che nel Senato. Meritatamente dalla S. Sede era stato decorato con la commenda di S. Gregorio Magno. Nell'ultima sessione del Senato contribui non poco per ottenere dal Governo una importante dichiarazione. Unito ad altri non molti suoi Colleghi appoggiò con vigore il Senatore Junqueira, che criticando abilmente il Ministero dell'Impero per la risposta data nella Camera dei Deputati all'interpellanza del celebre Saldanha Marinho gran-Maestro della Frammassoneria, della quale parlai nel mio foglio N. 26, con alcuni articoli di legge alla mano, quantunque generici, costrinse lo stesso Ministro a dichiarare, che il Governo riteneva veramente come abolite le antiche leggi contro la Compagnia di Gesù. Ev verso di me, come Rappresentante della S. Sede, si mostrava oltremodo benevolo ed ossequioso. Se alcuna volta mi pareva espediente che nel Senato si chiamasse l'attenzione del Governo sopra qualche interesse religioso, bastava che io gliene mostrassi la convenienza e l'utilità, perché lo facesse ala prima occasione con saggezza e senza ombra di rispetto umano. Accolga l'E. V. Revma. queste poche parole, anche come un tributo di riconoscenza ad un uomo si benemerito della Religione e della Chiesa. (Arquivo Secreto Vaticano, Negócios Eclesiásticos Extraordinários, Brasil, Ofício, 08/mar/1881, Fasc. 10 , pos. 203, f. $55 r-56 r$ ).

70

RODRIGUES J. H. Op. Cit. p. 17-19; SÁ VIANNA, Manuel Álvaro de Souza. Op. Cit.

71

VILLAÇA, Antônio Carlos. 0p. Cit. p. 65 e 83. nia final. Na ocasião foi diagnosticado que havia sofrido uma "congestão cerebral", um colapso provocado pelo afluxo anormal de sangue ao cérebro. Como bom católico que era, estava em dia com suas obrigações sacramentais, sendo acompanhado constantemente pelo seu diretor espiritual $\mathrm{Fr}$. Gregório Del Prato, capuchinho, que lhe havia confessado dias antes. No seu leito de enfermo, foi consolado pelo Padre Hehn, lazarista, reitor do Seminário Diocesano, e pelo Monsenhor Luis Brito, depois bispo de Olinda, que the deu a extrema-unção67.

Após a sua morte, muitas foram as vozes, mesmo entre os seus adversários políticos, que se levantaram para proclamarem admiração por esse homem de férreos princípios. Lacerda Almeida assim se referiria a ele:

Cândido Mendes morreu no exercicio das suas nobilíssimas funções, onde deu provas de seu valor intelectual sobre tudo em que esteve em jogo a causa do catolicismo. Cândido Mendes morreu paupérrimo, mostrando assim que as altas posições que ocupara Ihe foram ocasião de servir a Pátria e não de explorá-la ${ }^{68}$.

Por ocasião do seu falecimento, o Internúncio Angelo Di Pietro, representante pontifício no Brasil, escreveu um ofício no qual deixou claro quais eram os sentimentos da Santa Sé em relação a Cândido Mendes. 0 conteúdo desse documento ainda inédito fala por si, não tendo necessidade de digressões:

A defesa dos interesses católicos neste Império sofreu uma grande perda em 1 do corrente mês com a morte do senador Cândido Mendes de Almeida. Uma congestão cerebral que imediatamente lhe tirou o uso das faculdades mentais, o levou a uma outra vida na idade de cerca 60 anos. Ele era um homem muito erudito, genuinamente católico, especialista e defensor incansável do direito canônico, um inimigo declarado do exequatur, do placet e do regalismo; sempre o primeiro a falar, a protestar, e fazer tudo ao seu alcance para defender a Religião, a Igreja, a S. Sé e o clero, pelos 20 anos que autuou, tanto na Câmara dos Deputados quanto no Senado. Merecidamente, pela S. Sé, tinha sido condecorado com a comenda de S. Gregório Magno.

Na última sessão do Senado contribuiu, não pouco, para conseguir uma importante declaração por parte do Governo. Unido a outros poucos colegas apoiou com vigor o senador Junqueira, que habilmente criticou o Ministério do Império pela resposta dada a Câmara dos Deputados a interpelação do famoso grão mestre maçônico Saldanha Marinho, assunto ao qual já me referi na minha carta de N. 26. Com alguns artigos de lei na mão, apesar de genéricos, Candido Mendes obrigou 0 ministro a declarar que o Governo considerava como verdadeiramente abolidas as antigas leis contra a Companhia de Jesus.

E para comigo, como representante da S. Sé, ele sempre se demonstrou muito gentil e respeitoso. Se alguma vez me parecia conveniente que no Senado fosse chamada a atenção do Governo sobre algum interesse religioso, era suficiente que eu the mostrasse a conveniência e utilidade, para que ele o fizesse na primeira oportunidade que tivesse, com sabedoria e sem sombra de respeito humano.

Acolha E. V. Revma. estas poucas palavras, como um tributo de gratidão a um homem merecedor do benemérito da Religião e da Igreja ${ }^{69}$.

Em 1857, Cândido Mendes recebeu o Oficialato da Ordem da Rosa, e em 1860 a Comenda de São Gregório Magno por parte da Santa Sé7o. Segundo Villaça, o reconhecimento da Santa Sé aos serviços de Cândido Mendes era fortíssimo e, por isso, Pio $X$ concedeu a seus herdeiros o título de Conde. Também o episcopado o venerava pela "sua firmeza doutrinal, pela sua dedicação, pela sua coragem, pela sua perfeita modéstia"71. 
72

SÁ VIANNA, Manuel Álvaro de Souza. Op. Cit. p. 523.

73

ALMEIDA, Cândido Mendes de. Op. Cit. p. 12-13.

74

TORRES, João Camilo de Oliveira. História das Ideias Religiosas no Brasil. São Paulo: Grijalbo, 1968. p. 169-173.

\section{0 arauto do ultramontanismo no Brasil}

Agora deixaremos de lado a vida do nosso personagem para nos concentrarmos em alguns traços do seu pensamento político e religioso. É possivel encontrar em Cândido Mendes de Almeida várias facetas: o historiador, 0 geógrafo, o parlamentar, o jornalista; porém, duas delas marcaram fortemente o seu caráter: o jurista e o católico. Ao analisar a sua vida, percebese que esses seus dois traços estão profundamente ligados, pois ao defender e estudar as leis reforçava a sua posição em defesa da Igreja perante o Estado. Enquanto se imergia na espiritualidade católica, fortalecia o seu apego ao dever, às leis e à Constituição do seu país. Para Cândido Mendes, ser patriota era ser católico e defender a Constituição nacional. Ser católico para ele era ser fiel à ortodoxia, ao Papa, aos seus representantes no Brasil, aos bispos e à hierarquia em geral; em uma palavra, era ser ultramontano, adjetivo usado constantemente por seus adversários.

Sá Vianna, em 1918, apresentou muito bem como era a concepção de ultramontanismo no Brasil Imperial. Naquela época, este conceito tinha duas conotações divergentes e opostas: uma positiva, aceita pelos seus defensores; e outra negativa, utilizada pelos seus adversários. Vejamos este relato de Sá Vianna:

\footnotetext{
Sob o ponto de vista religioso Candido Mendes foi apresentado do mesmo modo injusto, como ocorrera politicamente: catholico intransgente, catholico intolerante, catholico reacionário, enfim, aggressivamente - ultramontano, ultramontano no mao sentido, nesse que o vulgo ignaro emprega por lh'o terem perversamente ensinado errado; ultramontano não procurando as origens do partido religioso que doutrinava e propagava a soberania do papa, mas o ultramontano, significando inimigo da Democracia, o hypocrita que se deve temer, o phanatico que se deve condenar, o pérfido do qual mal se pode fugir, tudo quanto é mao, posto em ação em nome de Deus e para perdição dos homens! E pensar, senhores, que houve Brasileiro que assim disseram e de tal modo pudessem julgar um patrício que, sob este aspecto, nem foi um asceta, mas um virtuoso; um subversor, mas um leal combatente, um crente que não solicitava o milagre em troca da oração, mas fazia-se merecedor da Graça pela prática sincera e abnegada do Bem ${ }^{72}$ !
}

A Igreja Católica era a religião oficial de acordo com a Constituição, e por meio desta Cândido Mendes buscou defendê-la. Perseguiu a "legalidade enquanto expressão e encarnação de uma vontade que transcendia o próprio homem", sempre preocupado com a sobrevivência legal dos valores e proposições do pensamento católico. No Senado, por dez vezes, tomou a palavra para tratar temas que tocavam direta ou indiretamente os problemas religiosos. Nesses discursos, apresentou suas teorias de interpretação jurídica brasileira, sendo que o seu conhecimento religioso "funcionava como fundamento metodológico da sua argumentação". A religião tornou-se para ele não apenas uma crença, mas uma forma de pensar e viver, resultando politicamente na sua defesa constante dos princípios conservadores monárquicos e, sobretudo, dos dogmas da Igreja Católica Apostólica Romana ${ }^{73}$. João Camilo de Oliveira Torres afirma que, em todas as manifestações públicas, parlamentares e nos escritos, Cândido Mendes foi um jurista de altos méritos e ultramontano consciente ${ }^{74}$. A sua adesão ao catolicismo ortodoxo, colocando-se do lado da Igreja perante o Estado, foi claramente desenvolvida na sua obra jurídico-histórica intitulada Direito Civil Eclesiástico Brasileiro antigo e moderno em suas relações com o direito canônico. Essa obra foi elaborada em dois volumes de aproximadamente 1.800 páginas. No primeiro volume, nas primeiras 424 páginas, Cândido expõe suas teses 
75

ALMEIDA, Cândido Mendes de. Direito Civil Eclesiástico Brasileiro Antigo e Moderno em suas relações com o Direito Canônico. Rio de Janeiro: Garnier, 1866. p. 4, 29.

76

Idem. p. 42

Idem. p. 194

78

Idem. p. 180-181. históricas e jurídicas sobre a formação do padroado e do regalismo português e brasileiro, elaborando suas criticas ao sistema que, segundo ele, sufocava a liberdade da Igreja e usurpava-Ihe poderes e direitos. No restante dos volumes, ele apresenta a documentação que reuniu, sendo que vários delas se achavam inéditas e escondidas nos arquivos de Portugal e Brasil.

Cândido Mendes critica severamente todas as medidas da coroa lusitana e brasileira que prejudicavam a liberdade da Igreja e a autoridade pontifícia, principalmente as introduzidas com o Código Filipino, com as reformas pombalinas e com a Constituição brasileira de 1824. Ele não esconde sua posição e a apresenta logo no prólogo, ao acusar o poder temporal de reduzir, pela legislação vigente, a liberdade e autonomia da Igreja Católica. As práticas regalistas que ele critica mais ferozmente são o Beneplácito Régio, o Recurso à Coroa e a implementação do Padroado Civil por meio da Constituição de 1824, que ele denomina de "padroado à força"75.

Cândido Mendes, alinhado com as diretrizes do Concílio de Trento, defende a autonomia da Igreja como sociedade dentro do Estado, com uma organização executiva, legislativa e judiciária que Ihe é própria. A Igreja não só seria autônoma, como superior ao Estado. Aproveita a ocasião para criticar a doutrina que ele chama de Galicana e que na sua opinião se inseriu em Portugal por meio do governo do Marquês de Pombal. Segundo ele, tal concepção defendia que a autoridade teria origem no Direito Divino e que o rei teria recebido o seu poder diretamente de Deus ${ }^{76}$.

Cândido Mendes, atacando o regalismo e o galicanismo, deixa claro qual seria a sua posição: o ultramontanismo. Ao diferenciar a sua doutrina daquela que critica, faz questão de demonstrar que aquela que defende carrega um germe revolucionário. Neste momento, ao leitor, talvez paire uma certa dúvida: como uma doutrina conservadora como a ultramontana pode ser revolucionária? Esses conceitos são por vezes difíceis de serem utilizados quando se analisam algumas doutrinas em ambientes sociais diferenciados. 0 ultramontanismo é sim um movimento de conservação da lgreja observando em escala mundial, no entanto, no Brasil ele é novidade, já que o tradicional era a Igreja luso-brasileira baseada no padroado e no regalismo. No Brasil imperial, no que se refere à Igreja, quem procura conservar é uma parte da classe política, são algumas alas da maçonaria, são alguns setores do governo, que buscavam de todas as formas manter a Igreja sob o rígido controle do Estado. Cândido Mendes não teme demonstrar que os ultramontanos teriam o direito de se revoltar contra tal governo em casos extremos:

\footnotetext{
Há ainda a de notar (...) entre a escola galicana e a ultramontana, esta diferença, que a segunda admite muito mais voluntariamente os limites do poder, e as garantias da liberdade dos súditos. Talvez mesmo os Doutores desta última escola não repugnem tanto como os da primeira em admitir casos extremos em que 0 povo poderia legitimamente derribar do seu trono um tirano que não usasse de sua autoridade senão para arruinar a sociedade, de que deveria ser o sustentáculo ${ }^{77}$.
}

Cândido Mendes questiona abertamente o direito de padroado no Brasil, que foi instaurado civilmente "à força", justificando-se na soberania dos estados e que, posteriormente, negou o beneplácito à bula Praeclarae Portugalliae com a qual, em 1827, o Papa havia concedido o padroado real e da Ordem de Cristo ao Imperador do Brasil. Na opinião de Cândido, esse direito teria se acabado de vez com a secularização das Ordens Militares católicas com um decreto publicado em 1843. Seu objetivo era traçar os contornos desse "padroado à força" e, segundo ele, ilegítimo ${ }^{78}$. 
79

Idem. p. 332, 355 e 389.

80

Idem. p. 70-71.

81

SANTIROCCHI, Ítalo Domingos. Os ultramontanos no Brasil. Op. Cit.

82

Arquivo Secreto Vaticano, Nunciatura Apostólica - Brasil, Despacho, 17/out/1873, Cx. 39 , fasc. 178 , doc. 60, f. $46 r-47$ r.

83

GOMES, Francisco José Silva. Le projet de neo-chrétienté dans la diocese de Rio de Janeiro 1969-1915. Tese (Doutorado em História). 1991. Université de Toulouse Le Mirail, Touluse. 1991; LEMOS, Jerônimo de. D. Pedro de Maria Lacerda. Rio de Janeiro: Iumen Christi, 1987: SANTIROCCHI, İtalo Domingos. Os ultramontanos. Op. Cit.

84

SANTIROCCHI, İtalo Domingos. Os ultramontanos. Op. Cit. p. 365-370.
Todavia, as críticas de Mendes não se dirigiam somente ao Estado, elas também foram endereçadas aos bispos que se calaram diante das usurpações estatais e fugiram da luta pelos seus direitos. Seguindo seu raciocínio, logo depois da independência, quando ainda existia a Mesa da Consciência no Brasil, o "regalismo à força" brasileiro dava como direito do Imperador "até mesmo a capacidade de colar ou de fazer colar até mesmo um secular". Isso dificilmente foi contrastado pelos bispos que eram "feituras do Padroado", e mesmo se se arriscassem a uma resistência seriam severamente contidos, mas estes "preferiam o silêncio, à luta e ao martírio". Concluía Cândido que o resultado disso foi a transformação dos empregados da Igreja em funcionários públicos. Cândido Mendes clama pela liberdade da Igreja, pois somente assim poderia ser levada adiante uma efetiva reforma do clero e para isso era necessária uma reação. E ela só poderia partir dos bispos, da hierarquia eclesiástica ${ }^{79}$.

Cândido Mendes esboçou no Direito Civil e Eclesiástico um projeto de reforma católica, que em vários pontos se aproximava daqueles elaborados pelo episcopado. Ele pregava que os prelados lutassem pela instauração de qualificados centros de formação do clero, pois só um clero bem formado poderia reformar o costume do povo. Ele sugere, na sua obra, a criação de faculdades católicas para suprir tais necessidades ${ }^{80}$.

Enquanto trabalhava no seu livro, Cândido Mendes presenciou as várias "crises" religiosas que envolveram questões como o matrimônio, as tentativas do Estado de apoderar-se dos bens das ordens religiosas e de interferir na administração dos seminários. Foi testemunha das dificuldades dos bispos D. Viçoso e D. Antônio Mello para disciplinarem seu clero, que constantemente recorria à Coroa, levando os casos ao Conselho de Estado. Ele deve ter recebido com tristeza, em 1858, a notícia de que as negociações para uma Concordata com a Santa Sé tinham falido ${ }^{81}$.

0 Direito Civil Eclesiástico de Cândido Mendes causou impressão geral, até mesmo em seus adversários. Obra muita bem redigida e incrivelmente documentada recebeu elogios até mesmo do Papa Pio IX $X^{82}$. Logo após a publicação do primeiro volume, Cândido Mendes teve o prazer de ver nomeado para a diocese do Rio de Janeiro o seu primeiro bispo ultramontano, D. Pedro de Maria Lacerda, discípulo de D. Viçoso, que assumiu a sede carioca em 1868. Agora, nosso personagem tinha a companhia de um bispo reativo, que dali a quatro anos iniciaria a "Questão Religiosa"83.

Em 1869, Cândido Mendes demonstrou suas qualidades de deputado católico e a sua inabalável posição em defesa da Igreja. Na sessão de 20 de julho de 1869, pronunciou um discurso na Câmara dos Deputados, de vasta repercussão, a respeito da proposta da lei do orçamento para o ano financeiro de 1869-1870. Nesses anos, o governo buscava abolir as ordens religiosas, ditas brasileiras, que estavam em via de ficarem sem religiosos por motivo da morte daqueles existentes e a proibição da entrada de noviços decretada em 1855. 0 intento do Estado era apoderar-se dos bens das corporações monásticas, vendendo-os e convertendo o respectivo produto em apólices da dívida pública inalienáveis. Essa contenda vai durar vários anos, até o fim do Periodo Imperia| ${ }^{84}$.

Nessa ocasião, Cândido Mendes travou a sua primeira luta política juntamente com os bispos ultramontanos e o Internúncio Domenico Sanguini. Ele vai combater ferozmente uma proposta orçamentária que impunha impostos crescentes sobre terrenos, prédios rústicos e outros bens pertencentes às ordens religiosas. Como era de sua feição, fez um discurso 
85

RODRIGUES J. H. Op. Cit. p. 20; SANTIROCCHI, Ítalo Domingos. Os ultramontanos. Op. Cit. p. 365-370.

86

DOMINGOS, Tiago Simone. Política e memória do IHGB: a defesa dos jesuitas a partir dos artigos Notas para a história pátria de Cândido Mendes publicados em 1877 e 1879. Anais do XIX Encontro Regional de História e Exclusão. São Paulo: ANPUH/SP-USP, 2008.

87

VILLAÇA, Antônio Carlos. Op. Cit. p. 80.

88

RODRIGUES J. H. Op. Cit. p. 13 e 22-25.

89

Idem. p. 34-36. erudito no qual declarou que estava ali para defender os direitos da Igreja. Reafirmou sua acusação de que a "Igreja neste país não tem liberdade, não obstante saber-se que a liberdade é o maior bem que a ela se pode fazer", e lastimou "que a missão de atacar e oprimir a Igreja caiba hoje por sorte ao partido a que tenho a honra de pertencer". Aproveitou a ocasião para estender sua crítica a todas as medidas regalistas do governo imperial. Seu discurso causou admiração entre os católicos e mudou os rumos da discussão na Câmara ${ }^{85}$.

Além de defender as ordens religiosas em geral, Cândido Mendes foi um defensor dos jesuitas, constantemente atacados pelos liberais e pelos regalistas ${ }^{86}$. Discutiu veementemente com Sousa Franco para defendê-los. Dizia ele a seu opositor: "Quando o adversário quer a supressão do seu contendor, para ficar só em campo, mediante o auxílio da força, patenteia a sua deficiência de razão, exibe claramente a sua incapacidade. A Maçonaria deveria travar em campo leal uma luta com os Jesuitas"87.

Quando os bispos resolveram desafiar o regalismo imperial, por ocasião da "Questão Religiosa", Cândido Mendes se colocou na primeira linha para defendê-los. Sobressaiu-se como um dos mais brilhantes defensores dos prelados, propondo-se como advogado espontâneo no julgamento de D. Vital, juntamente com Zacarias de Góis e Vasconcelos. Para Cândido Mendes, a Questão Religiosa era o fruto da aplicação do placet, ou melhor, sobre o entendimento constitucional do tema. Como já havia demonstrado no Direito Civil e Eclesiástico, ele se opunha veementemente a essa prática.

Durante as discussões em 1873, ele desenvolveu eruditos discursos nos quais citou bulas papais, a história da maçonaria em Portugal, no Brasil e no estrangeiro em geral, e a história da Igreja na luta contra as sociedades secretas. Buscou provar a incompatibilidade do Ministro Visconde do Rio Branco ser ao mesmo tempo chefe do gabinete e chefe da maçonaria, baseando-se no art. $5 .^{\circ}$ da constituição. Revoltou-se contra a teoria que identificava as doutrinas católicas e maçônicas e defendeu que os maçons não poderiam ser sepultados nos cemitérios católicos, devendo construir os seus próprios ${ }^{88}$.

Foi nesse ano, em 30 de junho de 1873, que Cândido Mendes de Almeida pronunciou um dos discursos mais longos publicados nos Anais do Senado, superando as 100 páginas. Versava sobre o Voto de Graças sobre a Política Religiosa do Ministério. Segundo José Honório Rodrigues, Cândido Mendes, "seguríssimo de saber teológico, canônico, de direito e história da Igreja em geral e da brasileira em especial, revelou toda a força mental, toda a capacidade jurídica, todo conhecimento histórico que acumulara". Para o referido autor, Cândido Mendes foi sempre assim: "o que fazia, era o melhor que podia; e o que podia, raríssimos podiam elaborar" 89 .

Esse discurso é muito relevante, porque nele o orador analisou a questão religiosa, o procedimento do bispo de Olinda, a impossibilidade de ser ao mesmo tempo católico e maçom e atacou vigorosamente a maçonaria. Nele conceituou o que é dogma, as heresias, os erros cometidos pela inconsciência de seus adversários, elaborou uma sucinta história da Igreja no Brasil, defendeu a entrada dos capuchinhos no país e o retorno dos jesuitas. Explanou sobre a condenação das sociedades secretas, a história da maçonaria e seus fins. Ele tomou posição em favor do Syllabus e da Quanta Cura, explicou a distinção entre o Papa e a Cúria Romana, entre bula e breve, os equívocos do Conselho de Estado e defendeu a sentença de interdito de D. Vital à Irmandade do Santíssimo Sacramento de Recife. 
90

ALMEIDA, Cândido Mendes de. O Discurso pronunciado, na Sessão de 30 de junho de 1873, pelo Senador Cândido Mendes de Almeida, na discussão do Voto de Graças sobre a Política Religiosa do Ministério. Rio de Janeiro: 1873; RODRIGUES J. H. Op. Cit. p. 22-25.

91

LUSTOSA, Antônio de Almeida. Dom Macedo Costa (Bispo do Pará), 2a ed. Belém: Secretaria de Estado e Cultura, 1991. p. 10; VIEIRA, Dilermando Ramos. Op. Cit. p. 278.
Cândido Mendes ainda explicou as diferentes versões do placet dadas pelo poder temporal e espiritual, defendendo que este, juntamente com o recurso à Coroa, dificultava e tensionava as relações entre o Estado e a Igreja o Império. Para ele, o placet atacava a jurisdição do Sumo Pontífice e, o recurso à Coroa, atacava a autoridade dos bispos, devendo ser este último admitido apenas em matérias temporais ${ }^{90}$.

No decorrer da Questão Religiosa, os católicos, almejando defender os direitos da Igreja e incentivar leis em seu favor, tentaram instituir associações e um partido católico. Para a fundação da organização político-partidária católica, tentou-se criar as Associações Católicas. Em 1874, no Rio de Janeiro, tentou-se criar um "diretório central", a Associação Católica Fluminense, sendo alguns dos seus fundadores: Cândido Mendes de Almeida, Manoel Antônio dos Reis, Leandro Bezerra, Tarquínio Bráulio de Souza Amaranto e Zacarias de Góis e Vasconcelos. Escolhida e instalada a mesa diretora, a Associação Católica Fluminense foi logo impedida pelas autoridades civis que lhe recusaram a personalidade jurídica. 0 Estado tinha mais receio da Igreja do que dos republicanos, que fundavam partidos e abriam associações por todos os lugares ${ }^{91}$.

Poderiamos continuar aqui relatando vários outros exemplos de ações que ligam Cândido Mendes ao movimento ultramontano no Brasil, poderíamos prosseguir citando trechos de suas obras ou discursos, ou analisá-los de forma sistemática, todavia, isso seria impossivel no espaço de um artigo e também seria inútil e enfadonho, já que o objetivo proposto aqui era demonstrar sua vinculação ao ultramontanismo e sua convicção católica, e não fazer uma exaustiva análise de suas ideias. 0 que foi até aqui apresentado é mais que suficiente para demonstrar a sua ortodoxia e a sua importância para o movimento de reforma católica no século XIX. Podemos então ir à conclusão.

\section{A coragem de ser só (conclusão)}

Um dos objetivos desse artigo foi demonstrar a riqueza da biografia de Cândido Mendes de Almeida e como ela possibilita analisar importantes aspectos da sociedade brasileira do século XIX. Utilizando-se das novas metodologias para a elaboração de biografias históricas, é possivel desfazer a construção intencional da imagem de um personagem histórico de certa celebridade e depois reconstruí-la incluindo novas informações e corrigindo desvios criados por motivos laudatórios ou não. Tudo isso buscando indicios que possam nos mostrar a inserção do personagem na sociedade de sua época, já que também se busca perceber a sociedade brasileira por meio do personagem.

Cândido Mendes, em sua trajetória e na de seus ascendentes diretos, atravessou importantes periodos da história do Brasil. Desde o povoamento do Maranhão, do processo de independência, passando pelo conturbado Período Regencial, até o Segundo Império em várias de suas fases. Pode-se, por meio de nosso personagem, perceber a mobilidade das grandes famílias entre Portugal e Brasil, com a chegada da família real em 1808, quando veio para o Brasil a avó de Cândido. A presença da corte no território nacional também trouxe para cá um contingente de militares, sendo um deles o pai de nosso personagem.

Todos aqueles que viviam no Brasil durante o início da década de 1820 não puderam se isentar de tomar parte dos acontecimentos que levaram à independência do Brasil. Nesse caso a família de Cândido Mendes 
se posicionou contrariamente à emancipação do Maranhão. As grandes famílias separadas em grupos de potentados provinciais e locais se dividiram ante o projeto de um país independente, e esse conflito se prolongou nas décadas seguintes em sangrentos conflitos que eclodiram principalmente na década de 1830, sendo os principais a Setembrada e a Balaiada. Os potentados se dividiram em cabanos e bem-te-vis e lutaram acirradamente por posições políticas, cargos públicos e militares. A violência da Balaiada, envolvendo também os escravos e trabalhadores livres pobres, assustou a ambos os lados e forçou uma diminuição dos níveis de violência nas disputas políticas, que poderiam colocar em risco todo o sistema.

Percebe-se, também, como os membros das elites políticas nacionais eram recrutados nas oligarquias locais que, utilizando suas fortunas, redes de relações e influência, fundavam jornais, dominavam postos da administração pública e outros meios para construírem uma base eleitoral e de controle provincial. Isso Ihes permitia elegerem-se e reelegerem-se para a Câmara dos Deputados e, quando possível, para o Senado. Após se estabilizarem na política, abandonavam a província e se estabeleciam na corte, onde poderiam entrar em um outro nivel de movimentação política e em outras redes de poder.

A especificidade de Cândido Mendes é ter se inserido, como laico, no movimento de reforma ultramontana que se iniciou no século XIX. Suas ligações familiares e provinciais the abriram o caminho até aos altos postos políticos, consolidando-se neles por meio do seu apego à ordem e à defesa da constituição, demonstrando os seus excelentes dotes jurídicos. Todavia, ao consolidar-se nos altos escalões da política nacional, posicionou-se contra o Estado e a favor da Igreja nas questões político/eclesiásticas, arriscando a continuidade de sua escalada política. Enquanto a maioria dos seus colegas se inseriu na política defendendo o sistema do regalismo brasileiro, nosso personagem teve a coragem de se arriscar defendendo o projeto oposto. Cândido Mendes enfrentou até mesmo o imperador Pedro II, cioso dos seus pretensos direitos sobre a Igreja do Brasil, para defender a autonomia da Igreja que na sua opinião era universal e estava sob a autoridade pontifícia. Cândido Mendes não foi o único exemplo disso, pois no partido liberal também existia um ultramontano de renome: Zacarias de Góes e Vasconcelos (1815-1877). 0 grupo dos leigos ultramontanos na Câmara e no Senado era numericamente irrisório, no entanto, extremamente preparado para defender suas causas.

Pela sua posição em favor do ultramontanismo, Cândido Mendes teve de pagar um preço: um crescente isolamento político. Essa sua cruzada em favor da reforma católica, juntamente com sua dedicação às pesquisas, à escrita, aos estudos e à família, o levou a uma vida de semirreclusão, contribuindo para a construção de sua imagem pública de homem constante e linear na sua moralidade e convicções, como visto no início deste artigo. Porém, num ponto temos de concordar com Villaça, as escolhas, o posicionamento político e o caráter de Cândido Mendes criaram-Ihe não poucas dificuldades na vida pública. É por esse motivo que Villaça afirma que:

A coragem de ser só, Cândido Mendes a teve, e a teve com uma intensidade impressionante ... Lutou contra muitos. E realmente se prejudicou, em termos de carreira, pela fidelidade à voz de Roma. 0 seu romanismo o incompatibilizou muito com o Imperador e seus áulicos. Teria talvez sido ministro. Teria recebido outras missões. Outras condecorações ${ }^{92}$. 
Outra consequência foi a dificuldade em ser admitido no IHGB, sendo que já tinha sido indicado por um dos seus membros mais eminentes em 1853, mas só seria distinguido com a condição de sócio honorário do Instituto em 1878, três anos antes de sua morte. Mas essa falta de reconhecimento não terminou com o Império e não foi obra somente da política oficial desse governo. Por defender um projeto diferente daquele do Estado, ao contrário de Varnhagen, foi esquecido pela historiografia brasileira. Os trabalhos que falam de Cândido Mendes são pouquíssimos, e sua produção historiográfica encontra-se ainda praticamente inexplorada. Cândido Mendes foi um dos primeiros a escrever uma história eclesiástica no Brasil, utilizando as correntes de teoria histórica em voga na sua época. Não foi só no âmbito eclesiástico que produziu; sua obra histórica engloba também a história social, política e jurídica. Apesar de o movimento ultramontano ter sido vitorioso no Brasil, a produção historiográfica de um dos seus campeões praticamente ficou no esquecimento. Mesmo depois de sua morte, Cândido Mendes continuou pagando o preço pela solidão de ser ultramontano. 